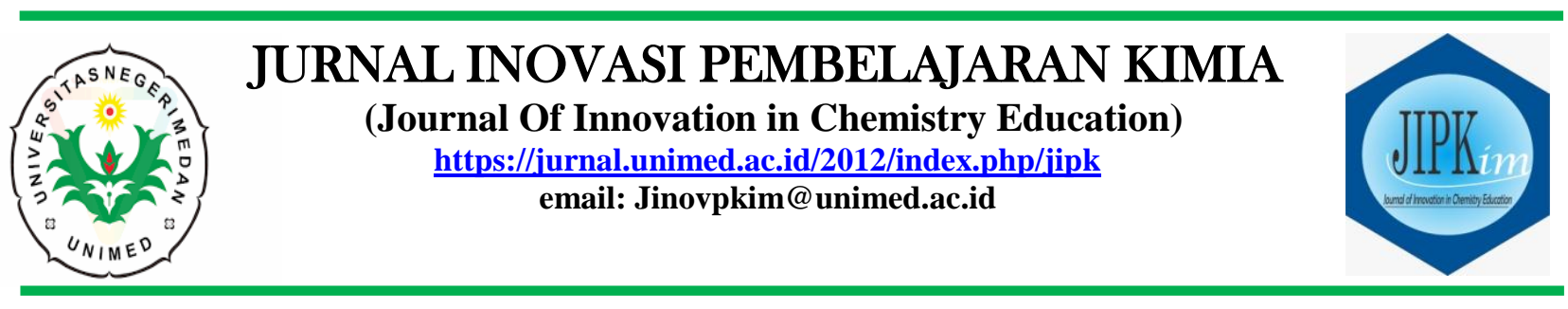

$\begin{array}{ll}\text { Masuk } & : 28 \text { Maret } 2021 \\ \text { Revisi } & : 6 \text { April } 2021 \\ \text { Diterima } & : 22 \text { April } 2021 \\ \text { Diterbitkan } & : 23 \text { April } 2021 \\ \text { Halaman } & : 76-85\end{array}$

\title{
Pengembangan Lembar Kerja Siswa (LKS) Berbasis Inkuiri Terbimbing Pada Pokok Bahasan Kesetimbangan Kimia
}

\author{
Lisnawaty Simatupang ${ }^{1 *}$, Indah Santika ${ }^{2}$ \\ ${ }^{1,2}$ Program Studi Pendidikan Kimia, Universitas Negeri Medan, Medan \\ *Alamat Korespondensi: lisnawaty@unimed.ac.id
}

\begin{abstract}
Student worksheets are sheets that are used as guidelines in learning and contain tasks that must be done by students in certain studies. This study aims to see: (1) The design of student worksheets based on guided inquiry on the subject of chemical equilibrium; (2) analyzing the feasibility of student worksheets based on guided inquiry learning; (3) analyzing the response of student and teacher attractiveness to student-based student worksheets based on guided inquiry. The research subjects were student worksheets based on guided inquiry. The object of research is the material of chemical equilibrium. The development of student worksheets refers to the research and development model of the Borg and Gall. This worksheet has been validated by validators and has been through small group trials to obtain valid and interesting results. The results of this study state that the student worksheets developed are very feasible based on the criteria content, language, presentation, guided inquiry, integration of character education, and graphics with consecutive percentages amounting to $86.67 \%$, $80 \%, 90 \%, 100 \%, 76.67 \%, 88.57 \%$. Meanwhile, the results of the attractiveness based on the responses of the teacher and students got a percentage of $90 \%$ and $88.85 \%$ respectively, with the very interesting category.
\end{abstract}

Keywords: Student Worksheets, Guided Inquiry, Chemical Equilibrium, eligibility

\section{PENDAHULUAN}

Ilmu kimia dipelajari bukan hanya untuk menguasai kumpulan pengetahuan berupa fakta, konsep, atau prinsip tetapi juga untuk mengetahui suatu proses penemuan dan penguasaan petunjuk atau metode ilmiah. Realita yang terjadi di sekolah bahwa mata pelajaran kimia dianggap sulit oleh sebagian besar siswa SMA, sehingga banyak dari siswa yang tidak berhasil dalam belajar kimia.
Selain itu, ada anggapan bahwa pelajaran kimia merupakan pelajaran yang menakutkan dan membosankan (Utari et al., 2018).

Kimia adalah salah satu mata pelajaran di SMA bagian IPA yang dianggap sulit sebagian siswa karena rumit dan bersifat abstrak, sehingga memerlukan pemahaman konsep secara mendalam yang dibelajarkan melalui pendekatan saintifik (scientific method), agar dapat memiliki pengetahuan dan keterampilan yang berkualitas, inovatif, 
kreatif, produtif, dan unggul, serta mampu memecahkan masalah yang di hadapinya sesuai kurikulum 2013 (Nainggolana et al., 2019).

Berdasarkan hasil wawancara dengan salah seoarang guru kimia di SMAN 1 Labuhan Deli, pembelajaran kimia saat ini sudah baik dan sesuai antara materi dengan tujuan pembelajaran. Dalam proses pembelajaran, siswa cukup aktif dan antusias, hal ini disebabkan karena materi kimia dapat diterapkan melalui praktikum, sehingga menarik minat siswa untuk belajar tetapi, dalam proses pembelajaran kimia belum menggunakan bahan ajar lembar kerja siswa (LKS) yang dikembangkan dengan model pembelajaran inkuiri terbimbing sebagai sumber belajarnya, namun hanya menggunakan buku pegangan yang diberikan disekolah tanpa ada tambahan sumber belajar lainnya.

Lembar kerja siswa merupakan aktivitas siswa dalam pembelajaran untuk menerapkan atau mempraktekkan ilmu yang telah diperoleh. Lembar kerja siswa tersebut sangat penting untuk mengetahui keberhasilan siswa dalam menyerap dan menguasai ilmu yang telah diberikan (Widodo, 2017). Lembar kerja siswa dapat mempermudah peserta didik untuk memahami materi yang diberikan, kaya akan tugas untuk berlatih dan melatih kemandirian belajar siswa, namun dengan adanya bahan ajar seperti LKS masih terdapat beberapa hambatan bagi siswa untuk memahami materi pelajaran. Hal ini disebabkan karena penggunaan bahasa yang digunakan kurang komunikatif artinya kata yang digunakan tidak dapat memotivasi siswa untuk membaca dan menumbuhkan rasa ingin tahu terhadap materi yang dijelaskan. Tampilan LKS yang sangat sederhana dan tanpa ilustrasi, serta kegiatan pembelajaran dalam LKS kurang bervariasi yang hanya menyajikan materi singkat dan kumpulan soal evaluasi. Sehingga perlu dikembangkan LKS dengan kegiatan pembelajaran yang lebih bervariasi (Ernawati et al., 2017).

Salah satu cara yang dapat digunakan guru dalam mengembangkan LKS dengan menerapkan model pembelajaran ke dalam
LKS. Model pembelajaran yang dapat dimasukkan dalam menyusun LKS salah satunya adalah inkuiri terbimbing. Model ini membantu siswa untuk mengembangkan tanggung jawab individual, kemampuan kognitif, kegiatan pemecahan masalah dan pemahaman keterampilan proses dan memahami materi yang diajarkan (Riyani \& Kusumo, 2017).

Model pembelajaran inkuiri merupakan suatu rangkaian kegiatan belajar yang melibatkan seluruh kemampuan siswa untuk mencari dan menyelidiki secara sistematis, kritis dan logis sehingga siswa dapat merumuskan penemuannya sendiri. jenis inkuiri yang cocok digunakan untuk tingkat SMA adalah inkuiri terbimbing, dikarenakan inkuiri terbimbing menyediakan lebih banyak arahan untuk para siswa yang belum siap untuk menyelesaikan masalah dengan inkuiri tanpa bantuan karena kurangnya pengalaman dan pengetahuan atau belum mencapai tingkat perkembangan kognitif yang diperlukan untuk berpikir abstrak. Dalam pembelajaran inkuiri terbimbing siswa memiliki kesempatan untuk menginvestigasi materi baik secara konseptual dan prosedural dengan arahan berupa pertanyaan dalam LKS (Utari et al., 2018).

Keberhasilan pengembangan lembar kerja berbasis Inkuiri Terbimbing sebagai bahan ajar telah ditunjang oleh berbagai penelitian, di antaranya, Mawan dan Rusmini (2017) menyatakan bahwa Lembar kerja siswa yang telah dikembangkan dinyatakan sangat layak berdasarkan kriteria isi, bahasa, penyajian, kegrafikan, inkuiri terbimbing, serta keterampilan proses sains, dengan persentase berturut-turut sebesar: 96,67\%, $95 \%, 85,56 \%, 90 \%, 93,33 \%, 93,33 \%$. Lembar kerja siswa ini mendapatkan respon yang sangat baik dari siswa dengan persentase sebesar 97,15\%.. Penelitian lain yang dilakukan oleh Utari et al, (2018) menunjukkan bahwa hasil analisis kevalidan aspek materi, media dan bahasa menunjukkan nilai koefisien validitas masing-masing sebesar 1,00 dengan kriteria sangat tinggi. 
Selain itu, berdasarkan hasil analisis keefektifan, yang didasarkan pada analisis hasil belajar setelah menggunakan LKS praktikum berbasis inkuiri terbimbing untuk uji coba lapangan awal dan utama berturutturut adalah $77,78 \%$ dan $76,47 \%$ yang telah memenuhi kriteria aspek keefektifan.

Berdasarkan latar belakang masalah diatas, maka peneliti tertarik melakukan penelitian yang berjudul "Pengembangan Lembar Kerja Siswa (LKS) Berbasis Model Pembelajaran Inkuiri Terbimbing Pada Pokok Bahasan Kesetimbangan Kimia".

\section{KAJIAN LITERATUR}

Lembar kerja siswa (LKS) adalah lembaran-lembaran yang digunakan sebagai pedoman di dalam pembelajaran serta berisi tugas yang harus dikerjakan oleh peserta didik dalam kajian tertentu (Fannie \& Rohati, 2014). Berdasarkan pengertian Lembar Kerja Siswa (LKS), maka terdapat fungsi dari LKS itu sendiri. Fungsi LKS sebagai: (1) Sebagai bahan ajar yang bisa meminimalkan peran pendidik, namun lebih mengaktifkan peserta didik, (2) Sebagai bahan ajar yang mempermudah peserta didik untuk memahami materi yang diberikan, (3) Sebagai bahan ajar yang ringkas dan kaya akan tugas untuk berlatih, (4) Memudahkan pelaks anaan pengajaran kepada peserta didik (Wahidah et al., 2018).

Inkuiri merupakan suatu pendekatan pada pembelajaran yang melibatkan suatu proses penyelidikan yang alami dan mendorong siswa untuk bertanya, membuat penemuan dan menguji penemuan itu melalui penelitian dalam pencarian suatu pemahaman atau konsep baru. Salah satu pendekatan inkuiri yaitu pendekatan inkuiri terbimbing dimana siswa memperoleh konsep secara mandiri melalui bimbingan. Bimbingan dapat berupa petunjuk dari guru, atau lembar kerja siswa yang terstruktur (Mawan \& Rusmini, 2017).

Bilgin (dalam Rahmi and Roza, 2019) mengambarkan inkuiri terbimbing sebagai pendekatan yang berpusat pada siswa. Pendekatan ini memiliki pengaruh positif terhadap keberhasilan akademik siswa dan mengembangkan keterampilan proses ilmiah serta sikap ilmiah mereka. Hasil penelitian yang dilakukan oleh Bilgin menunjukkan hasil yang signifikan setelah menggunakan model inkuiri terbimbing. Para siswa yang menggunakan model guided inquiry menunjukkan kinerja yang lebih baik dari siswa yang berada dikelas kontrol.

Penggunaan model pembelajaran Inkuiri Terbimbing (Guided Inquiry) merupakan salah satu solusi dalam memperbaiki kualitas pembelajaran kimia yang terjadi saat ini disekolah karena dengan model pembelajaran inkuiri terbimbing yang memiliki karakteristik melakukan percobaan akan melatih siswa meningkatkan keterampilan proses sains dan hasil belajar mereka (Juniar et al., 2019).

\section{METODE}

Penelitian ini merupakan penelitian pengembangan atau sering disebut dengan research and development ( $R$ and $D$ ) yaitu penelitian Borg dan Gall. Ada sepuluh langkah penelitian dan pengembangan sebagai berikut :

1) Penelitian dan pengumpulan data (research and information collection), 2) Perencanaan (planning), 3) Pengembangan draf produk (develop preliminary form of product), 4) Uji coba lapangan awal (preliminary field testing), 5) Revisi hasil uji coba (Main Product revision), 6) Uji coba lapangan (main field testing), 7) Penyempurnaan produk hasil uji lapangan (operasional product revision), 8) Uji pelaksanaan lapangan (operasional field testing), 9) Penyempurnaan produk akhir (final product revision), 10) Diseminasi dan implementasi (dissemination and implementation). Untuk dapat menghasilkan produk tertentu digunakan penelitian yang bersifat analisis kebutuhan dan untuk menguji keefektifan produk tersebut supaya dapat berfungsi dimasyarakat luas, maka diperlukan penelitian untuk menguji keefektifan produk tersebut (Sugiono,2010).

Dalam penelitian dan pengembangan yang dilakukan, penulis membatasi langkah- 
langkah penelitian dan pengembangan dari sepuluh langkah, hanya sampai tahapan kelima saja. Hal ini merujuk pada pendapat Wina Sanjaya dalam Oktavia (2018) bahwa Brog and Gall memiliki sepuluh tahapan, namun sepuluh tahapan tersebut dapat disederhanakan tanpa mengurangi nilai penelitian dan pengembangan itu sendiri. Selain itu, tujuan penelitian ini adalah ingin mengetahui kelayakan media yang dikembangkan, serta mengingat keterbatasan waktu dan biaya.

\section{Subjek dan Objek Penelitian}

Subjek penelitian adalah sesuatu yang sangat penting kedudukannya di dalam penelitian. Subjek pada penelitian ini adalah Lembar Kerja Siswa (LKS) berbasis Model Pembelajaran Inkuiri Terbimbing. Sedagkan Objek penelitian adalah sesuatu yang menjadi pemusatan pada kegiatan penelitian, atau dengan kata lain segala sesuatu yang menjadi sasaran penelitian. Sehingga dalam penelitian ini yang menjadi objek penelitiannya adalah materi kesetimbangan kimia. LKS yang menjadi produk dalam penelitian ini akan divalidasi oleh validator ahli materi dan validator ahli media. Selain itu, akan dilihat juga respon guru dan siswa dengan menggunakan angket dimana siswanya terdiri dari 20 orang.

\section{Prosedur Penelitian}

Prosedur dalam penelitian sesuai dengan rancangan penelitian research and development ( $\mathrm{R} \& \mathrm{D})$ yaitu penelitian Borg dan Gall. Ada sepuluh langkah penelitian dan pengembangan sebagai berikut :

1)Penelitian dan pengumpulan data (research and information collection)

2)Perencanaan (planning)

3)Pengembangan draf produk (develop preliminary form of product).

4) Uji coba lapangan awal (preliminary field testing).

5)Revisi hasil uji coba (Main Product revision).

6) Uji coba lapangan (main field testing).

7)Penyempurnaan produk hasil uji lapangan (operasional product revision).
8)Uji pelaksanaan lapangan (operasional field testing).

9)Penyempurnaan produk akhir (final product revision).

10) Diseminasi dan implementasi (dissemination and implementation).

Dalam penelitian dan pengembangan yang dilakukan, penulis membatasi langkahlangkah penelitian dan pengembangan dari sepuluh langkah, hanya sampai tahapan kelima saja. Hal ini merujuk pada pendapat Wina Sanjaya dalam Oktavia (2018) bahwa Brog and Gall memiliki sepuluh tahapan, namun sepuluh tahapan tersebut dapat disederhanakan tanpa mengurangi nilai penelitian dan pengembangan itu sendiri. Selain itu, tujuan penelitian ini adalah ingin mengetahui kelayakan media yang dikembangkan serta mengingat keterbatasan waktu dan biaya.

\section{Teknik Analisis Data}

Teknik analisis data dalam penelitian ini berupa kualitatif dan kuantitatif.

a. Angket kebutuhan

Angket kebutuhan dalam pengembangan produk ini akan dianalisis menggunakan deskriptif kualitatif dengan cara penyajian data melalui beberapa pertanyaan sesuai dengan keadaan dan kebutuhan yang ada pada saat penelitian tanpa adanya perhitungan didalamnya semua di jabarkan dalam bentuk deskriptif.

b. Angket Validasi

Instrument validasi berisi pertanyaan yang telah disediakan oleh peneliti. Nilai akhir suatu butir merupakan persentase nilai rata-rata dari perindikator dari seluruh jawaban validator. Dari perhitungan skor masing-masing pernyataan, dicari persentasi jawaban keseluruhan responden dengan rumus :

$$
P=\frac{\sum x}{\sum x i} \times 100 \%
$$

Keterangan :

$\mathrm{P} \quad$ : Persentase

$\sum \mathrm{x}:$ Jumlah jawaban responden dalam satu item 
Exi : Jumlah nilai ideal dalam item

Nilai akhir suatu butir merupakan persentase nilai rata-rata dari perindikator dari seluruh jawaban responden. Rumus untuk menghitung nilai rata-rata per indikator adalah sebagai berikut :

$$
\bar{X}=\frac{\sum x}{N}
$$

Keterangan:

$\overline{\boldsymbol{X}}=$ Nilai rata-rata per aspek penilaian

$\sum \mathrm{X}=$ Jumlah total skor dari responden

$\mathrm{N}$ = Jumlah responden

Kemudian dicari persentase kriteria validasi. Adapun kriteria validasi yang digunakan dapat dilihat pada tabel sebagai berikut :

Tabel I Konversi Interval Persentase menjadi

\begin{tabular}{cc} 
Kategori (Kelayakan) & \\
\hline Interval & Kriteria \\
\hline $80<\mathrm{X} \leq 100 \%$ & Sangat layak \\
$60<\mathrm{X} \leq 80 \%$ & Layak \\
$40<\mathrm{X} \leq 60 \%$ & Cukup \\
$20<\mathrm{X} \leq 40 \%$ & Tidak Layak \\
$0<\mathrm{X} \leq 20 \%$ & Sangat Tidak Layak
\end{tabular}

c. Angket tanggapan guru dan siswa

Angket tanggapan digunakan untuk mengumpulkan data mengenai tanggapan guru dan siswa terhadap Lembar Kerja Siswa yang dikembangkan. Penentuan kriteria interpretasi skor angket dapat dilihat pada tabel berikut ini:

Tabel 2 Konversi Interval Persentase menjadi Kategori (Kemenarikan)

Interval Kriteria

\begin{tabular}{cc}
\multicolumn{2}{c}{ Kategori (Kemenarikan) } \\
\hline Interval & Kriteria \\
\hline $80<\mathrm{X} \leq 100 \%$ & Sangat menarik \\
$60<\mathrm{X} \leq 80 \%$ & menarik \\
$40<\mathrm{X} \leq 60 \%$ & Cukup \\
$20<\mathrm{X} \leq 40 \%$ & Tidak menarik \\
$0<\mathrm{X} \leq 20 \%$ & Sangat Tidak menarik
\end{tabular}


digunakan oleh siswa hanya buku paket yang diberikan kepada sekolah dan belum menggunakan lembar kerja siswa berbasis inkuiri terbimbing. Metode yang sering digunakan saat pembelajaran yaitu metode ceramah dan diskusi biasa. Kesulitan belajar juga dialami siswa seperti penalaran konsep, menganalisis dan memecahkan masalah serta pemahaman dalam perhitungan kimia.

\section{Perencanaan Produk}

Proses pembuatan lembar kerja siswa (LKS) ini dengan menggunakan basis inkuiri terbimbing pada pokok bahasan inkuiri terbimbing pada pokok bahasan kesetimbangan kimia. Langkah-langkah penyusunan desain produk LKS ini, antara lain yaitu menyesuaikan kompetensi dasar berdasarkan kurikulum K13. LKS ini menggunakan model pembelajaran inkuiri terbimbing pada pokok bahasan kesetimbangan kimia yang menggunakan ukuran kertas A4.

Halaman isi LKS terdiri dari uraian materi, kegiatan praktikum, contoh soal, uji kompetensi, serta langkah-langkah model pembelajaran inkuiri terbimbing yang terdiri dari penyajian masalah, merumuskan hipotesis, pengumpulan data, menguji hipotesis, dan analisis kesimpulan. Pada cover belakang LKS terdapat tokoh ilmuwan kimia sebagai media untuk memotivasi siswa dalam belajar yang diambil dari berbagai sumber.

\section{Pengembangan Produk}

Pada tahap ini mulai disusun rancangan awal LKS berbasis inkuiri terbimbing dan instrumen yang dibutuhkan dalam penelitian. Kemudian dilakukan validasi terhadap rancangan awal produk oleh pakar yang ahli dalam bidangnya. Sebelum diuji cobakan pada siswa, LKS berbasis inkuiri terbimbing harus divalidasi terlebih dahulu. Validasi dilakukan untuk mengetahui kelayakan lembar kerja siswa berbasis inkuiri terbimbing pada pokok bahasab kesetimbangan kimia. Validasi dilakukan oleh total 4 orang validator dari 2 macam ranah validasi, yaitu validasi ahli materi dan validasi ahli media. Proses ini dilakukan untuk mengoreksi LKS berbasis inkuiri terbimbing yang telah disusun sebelumnya dan hasilnya digunakan sebagai acuan dalam proses revisi.

Selain instrumen validasi diberikan kepada validator, peneliti juga memberikan istrumen kepada 2 guru bidang studi kimia untuk mengetahui respon terhadap produk yang dikembangkan. Instrumen validasi menggunakan skala Likert. Adapun hasil validasi adalah sebagai berikut:

a. Validasi ahli materi

Penilaian LKS oleh ahli materi dilakukan dengan menggunakan instrumen penilaian, ialah lembar validasi berisi aspekaspek kriteria yang sudah ditetapkan. Hasil validasi dapat dilihat pada Gambar 1.

Gambar 1. Hasil Persentase Ahli Materi

\section{Hasil Validator Ahli Materi}

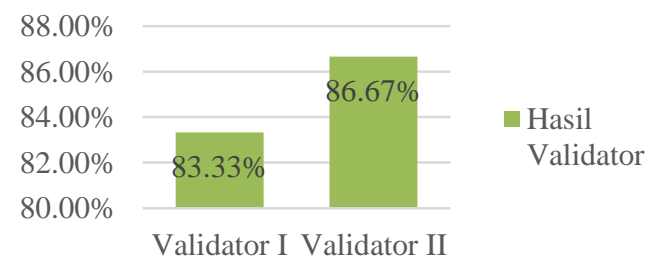

Berdasarkan Gambar 1 dapat dilihat bahwa penilaian validator I dan II terhadap LKS yang dikembangkan memperoleh kualitas sangat layak dengan persentase berturut-turut sebesar $83,33 \%$ dan $86,67 \%$.

\section{b. Validasi ahli media}

Penilaian dan penentuan kriteria interpretasi ahli media disesuaikan dengan penilaian dan penentuan kriteria interpretasi pada validasi ahli materi. Hasil validasi dapat dilihat pada Gambar 2.

\section{Hasil Validasi Ahli Media}

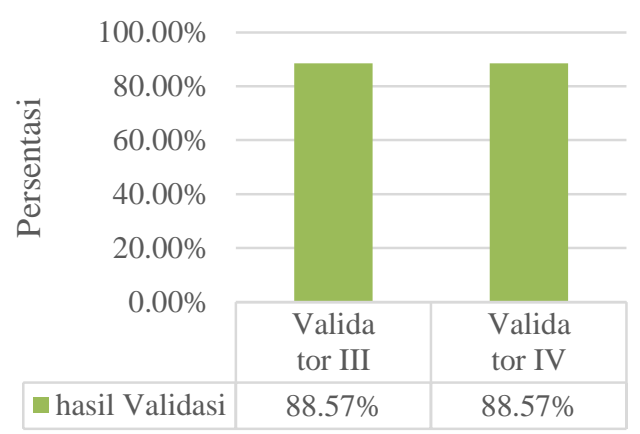

Gambar 2. Hasil Persentase Ahli Media 
Berdasarkan Gambar 2 dapat dilihat bahwa penilaian validator III dan IV terhadap LKS yang dikembangkan memperoleh kualitas sama yaitu sangat layak dengan persentase sebesar $88,57 \%$.

\section{c. Tanggapan guru kimia}

Hasil Tanggapan dua orang responden guru bidang studi kimia terhadap lembar kerja siswa (LKS) berbasis inkuiri terbimbing seperti yang terlihat pada Gambar 3.

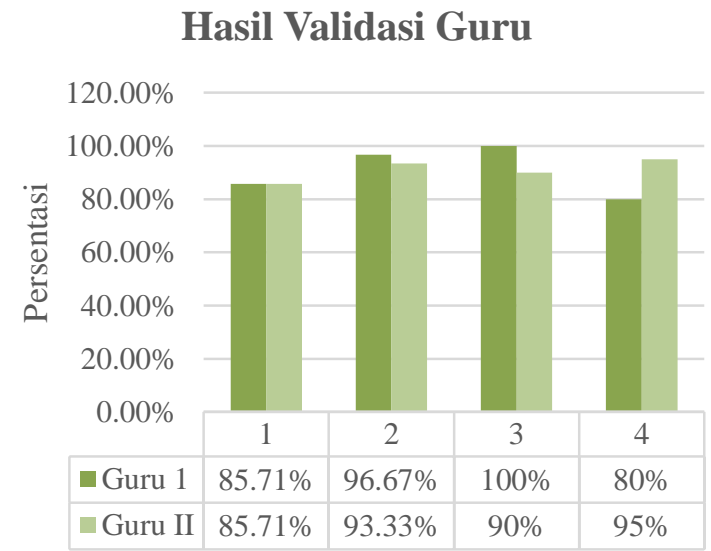

Gambar 3. Hasil Presentase Respon Guru

Berdasarkan Gambar 3 diketahui bahwa hasil penilaian respon guru dari masing-masing guru adalah respon guru Bapak Zulpahman memberikan skor dengan persentase rata-rata $90,60 \%$ dan dinyatakan dalam kriteria Sangat Menarik, dengan rincian aspek materi persentase yang dicapai adalah $85,71 \%$, aspek penyajian mencapai $96,67 \%$, aspek inkuiri terbimbing dengan persentase $100 \%$, aspek bahasa mencapai persentase $80 \%$. Sedangkan guru II Bapak Muhammad Aslan memberikan skor dengan persentasi rata-rata $91,01 \%$ dan dinyatakan dalam kriteria sangat menarik, dengan rincian aspek materi persentasi yang dicapai adalah $85,71 \%$, aspek penyajian mencapai $93,33 \%$, aspek inkuiri terbimbing dengan persentasi $90 \%$, serta aspek bahasa mencapai persentasi $95 \%$. Hasil penilaian dari guru bidang studi kimia mendapatkan nilai rata-rata persentase kelayakan rata-rata sebesar $90,00 \%$.

\section{Uji Coba Lapangan Awal}

Setelah dilakukan revisi berdasarkan validasi para ahli dan guru, kemudian dilakukan uji coba LKS. Uji coba termasuk dalam rangkaian evaluasi dalam pengembangan. Pada tahap ini diujicobakan pada kelompok kecil. Pengujian ini dilakukan dengan tujuan untuk menguji kemenarikan LKS yang telah dikembangkan berdasarkan penilaian siswa.

Peneliti melakukan tahap uji kelompok kecil kepada 20 orang siswa SMA kelas XI IPA. Karena pandemic Covid-19 peneliti melakukan uji coba kelompok kecil melalui bantuan guru kimia SMA yaitu dengan memberikan link google form (gform) ke dalam WhatsApp group kelas XI MIA 4. Dalam link gform tersebut sudah terdapat petunjuk mengisi angket serta terdapat link LKS yang dibuat dalam bentuk google drive (gdrive). Setelah itu, responden atau siswa diminta untuk memberikan penilaian dengan cara mengisi kuisioner atau angket tersebut. Hasil respon siswa dapat dilihat pada Gambar 4.

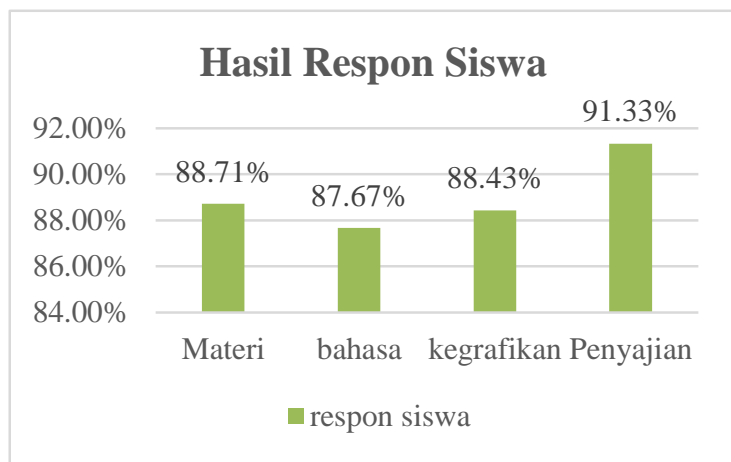

Gambar 4. Hasil Persentase Respon Siswa

Berdasarkan Gambar 4 diketahui bahwa hasil uji coba kelompok kecil, pada aspek materi mencapai persentase $88,71 \%$, aspek bahasa mencapai persentase $87,67 \%$, pada aspek kegrafikan mencapai persentase $88,43 \%$, dan aspek penyajian mencapai persentase $91,33 \%$. Keseluruhan jumlah persentase tersebut mencapai kriteria sangat menarik. Sehingga, dapat disimpulkan bahwa menurut siswa, LKS yang dikembangkan sangat menarik sebagai media pembelajaran. Hal ini didukung oleh penelitian yang dilakukan oleh Abdurrohim, dkk (2016) mengenai pengembangan lembar kegiatan siswa (LKS) berbasis inkuiri terbimbing pada materi hidrolisis garam bahwa hasil uji coba kepada siswa yaitu pada aspek kegrafisan 
memperoleh persentase sebesar 84,39\%, aspek kelayakan isi memperoleh persentase sebesar 81,47\%, aspek inkuiri terbimbing memperoleh persentase sebesar $81,22 \%$ dan aspek bahasa memperoleh persentase sebesar $79,39 \%$. Secara keseluruhan, rata-rata persentase LKS yang dikembangkan sebesar $81,62 \%$ termasuk dalam kategori layak dengan kriteria sangat baik.

\section{Revisi Hasil Uji Coba Revisi}

LKS hasil uji coba lapangan awal dilakukan berdasarkan kuisoner/angket yang telah diisi oleh siswa terhadap LKS berbasis inkuiri terbimbing. Hasil yang didapatkan dari uji coba lapangan awal pada penelitian ini berupa respon positif dari semua siswa yang menjadi sampel. Respon positif ini ditunjukkan pada hasil analisis data dari angket respon yang telah diisi siswa. Pernyataan-pernyataan yang terdapat dalam angket respon siswa ini terdiri dari pernyataan positif dan pernyataan negatif. Butir pernyataan positif terdiri dari 16 pertanyaan/pernyataan. Sedangkan butir pernyataan negatif terdiri dari 4 pernyataan/pertanyaan.

\section{DISKUSI}

Hasil Penelitian ini menyatakan bahwa lembar kerja siswa yang dikembangkan sangat layak berdasarkan kriteria isi, bahasa, penyajian, inkuiri terbimbing, integrasi pendidikan karakter, dan kegrafikan dengan persentase berturut-turut sebesar 86,67\%, 80\%, 90\%, 100\%, 76,67\%, $88,57 \%$. Sementara itu hasil kemenarikan LKS berdasarkan respon guru dan siswa mendapatkan presentase berturut-turut sebesar $90 \%$ dan $88,85 \%$ dengan katagori sangat menarik. Hal ini didukung oleh penelitian yang dilakukan oleh Pratiwi, dkk (2015) mengenai pengembangan LKS praktikum berbasis inkuiri terbimbing pada pokok bahasan larutan penyangga. Hasil penelitian menunjukkan bahwa penilaian ahli materi terhadap LKS praktikum berbasis inkuiri yang dikembangkan baik dengan persentase penilaian sebesar $81 \%$. Selanjutnya Abdurrohim, dkk (2016) pada penelitiannya mengenai pengembangan lembar kegiatan siswa (LKS) berbasis inkuiri terbimbing pada materi hidrolisis garam menunjukkan bahwa LKS yang dikembangkan memiliki kategori layak dengan kriteria sangat baik dengan persentase rata-rata sebesar $81,62 \%$.

Wahyuningsih, dkk (2014) bahwa pengembangan LKS berbasis inkuiri terbimbing pada materi pokok hidrolisis garam dinyatakan layak digunakan berdasarkan penilaian ahli media. Mayasari dan Bertha (2019) pada penelitiannya mengenai pengembangan lembar kerja siswa berbasis inkuiri terbimbing untuk melatihkan keterampilan berpikir kreatif pada materi laju reaksi juga menunjukkan bahwa penilaian ahli terhadap LKS yang dikembangan sangat valid berdasarkan kriteria kegrafisan dengan persentase sebesar $81,25 \%$.

\section{KESIMPULAN}

Berdasarkan hasil analisis data yang telah dilakukan dalam penelitian ini, maka dapat ditarik kesimpulan sebagai berikut : Rancangan lembar kerja siswa (LKS) berbasis inkuiri terbimbing yang dihasilkan dan dikembangkan mengacu pada model pengembangan Borg and Gall. Penulis membatasi tahapan penelitian dan pengembangan dari 10 tahap menjadi 5 tahap yang terdiri atas tahap penelitian dan pengumpulan informasi, tahap perencanaan produk, tahap pengembangan produk, tahap uji coba lapangan awal, serta tahap revisi hasil uji coba, dimana kelayakan LKS yang dikembangkan dinilai berdasarkan kriteria layak dan menarik.

Kelayakan lembar kerja siswa (LKS) berbasis inkuiri terbimbing pada pokok bahasan kesetimbangan kimia berdasarkan penilaian ahli materi mencapai pesentase rata-rata sebesar $85 \%$ dengan kriteria sangat layak dan ahli media memberikan penilaian dengan persentase rata-rata sebesar $88,57 \%$ dengan kriteria sangat layak.

Tingkat kemenarikan lembar kerja siswa (LKS) berbasis inkuiri terbimbing pada pokok bahasan kesetimbangan kimia 
berdasarkan respon guru adalah sebesar $90,00 \%$ dengan kriteria sangat menarik. Tingkat kemenarikan berdasarkan respon siswa SMA kelas XI IPA dalam uji coba kelompok kecil mendapatkan kriteria sangat menarik dengan persentase $88,85 \%$. Hal ini menunjukkan bahwa LKS yang dikembangkan sangat menarik bagi guru maupun siswa, sehingga dapat digunakan sebagai salah satu media penunjang dalam pembelajaran.

\section{DAFTAR PUSTAKA}

Abdurrohim, Feronika, T., \& Bahriah, E. S. (2016). Pengembangan Lembar Kegiatan Siswa (LKS) Berbasis Inkuiri Terbimbing Pada Materi Hidrolisis Garam. Jurnal Penelitian Dan Pembelajaran IPA, 2(2), 197-212.

Ernawati, A., Ibrahim, M. M., \& Afiif, A. (2017). Pengembangan Lembar Kerja Siswa Berbasis Multiple Intelligences Pada Pokok Bahasan Substansi Genetika Kelas Xii Ipa Sma Negeri 16 Makassar. Jurnal Biotek, 5(2), 1-18.

Fannie, R. D., \& Rohati. (2014). Pengembangan Lembar Kerja Siswa (LKS) Berbasis POE (Predict, Observe, Explain) Pada Materi Program Linier Kelas XII SMA. Jurnal Sainmatika, 8(1), 96-109.

Juniar, A., Mistryantob, P., Saplaa, N., \& Dewi. (2019). Pengaruh Penerapan Model Inkuiri Terbimbing Terhadap Pengaruh Penerapan Model Inkuiri Terbimbing Terhadap Keterampilan Proses Sains dan Hasil Belajar Siswa. Jurnal InovasiPendidikan Kimia, 1(1), 23-31.

Mawan, A. R., \& Rusmini. (2017). Pengembangan Lembar Kerja Siswa Berorientasi Inkuiri Terbimbing Untuk Melatih Keterampilan Proses Sains Pada Materi Kesetimbangan Kimia. UNESA Journal of Chemical Education, 6(3), 435-439.

Mayasari, P. I. K., \& Yonata, B. (2019). Pengembangan Lembar Kerja Siswa
Berbasis Inkuiri Terbimbing Untuk Melatihkan Keterampilan Berpikir Kreatif Pada Materi Laju Reaksi. Unesa Journal Of Chemical Education, 8(2), 259-265.

Nainggolana, B., Hutabarata, W., \& Gultom, L. (2019). Pengembangan Penuntun Praktikum Kimia Inovatif Terintegrasi Pembelajaran Berbasis Proyek dan Karakter Pada Materi Koloid. Jurnal Inovasi Pembelajaran Kimia, 1(2), 5057.

Pratiwi, D. M., Saputro, S., \& C.S, A. N. (2015). Pengembangan LKS Praktikum Berbasis Inkuiri Terbimbing Pada Pokok Bahasan Larutan Penyangga Kelas XI IPA SMA. Jurnal Pendidikan Kimia (JPK), 4(2), 32-37.

Riyani, A. F., \& Kusumo, E. (2017). Pengembangan Lembar Kerja Siswa Berpendekatan Inkuri Terbimbing Pada Konsep Kelarutan. Jurnal Inovasi Pendidikan Kimia, 11(2), 2008-2019.

Utari, wiji tri, Fadhilah, R., \& Fitriani. (2018). Pengembangan Lembar Kerja Siswa (LKS) Praktikum Berbasis Inkuiri Terbimbing Pada Materi Larutan Penyangga Di SMA Negeri 4 Sungai Raya. Ar-Razi Jurnal Ilmiah, 6(1), 6978.

Wahidah, N., Hasanuddin, \& Hartono. (2018). Pengembangan Lembar Kerja Siswa dengan Model Pembelajaran Koperatif Tipe Kreatif-Produktif untuk Memfasilitasi Kemampuan Pemahaman Konsep Matematis Siswa SMP Negeri 21 Pekanbaru. JURING (Journal for Research in Mathematics Learning), 1(1), 79-90.

Wahyuningsih, F., Saputro, S., \& Mulyani, S. (2014). Pengembangan Lks Berbasis Inkuiri Terbimbing Pada Materi Pokok Hidrolis Garam Untuk SMA/MA. Jurnal Paedagogia, 17(1), 94-103.

Widodo, S. (2017). Pengembangan Lembar Kegiatan Peserta Didik (LKPD) berbasis Pendekatan Saintifik untuk 
Meningkatkan

Keterampilan

Penyelesaian Masalah Lingkungan

Sekitar Peserta Didik di Sekolah Dasar.

JPIS Jurnal Pendidikan Ilmu Sosial, 26(2), 189-204. 